\title{
Demostración de tuberculosis en una momia prehispánica colombiana por la ribotipificación del ADN de Mycobacterium tuberculosis
}

\author{
Hugo Sotomayor ${ }^{1}$, Javier Burgos ${ }^{2}$, Magnolia Arango ${ }^{3}$ \\ 1 Facultad de Medicina, Universidad Militar Nueva Granada, Bogotá, D.C., Colombia. \\ 2 Facultad del Medio Ambiente y Recursos Naturales, Universidad Distrital Francisco José de Caldas, \\ Bogotá, D.C., Colombia. \\ ${ }^{3}$ Facultad de Medicina, Universidad Nacional de Colombia, Bogotá D.C., Colombia. \\ La momia en estudio perteneció a la sociedad prehispánica guane. Según consta en la ficha \\ de clasificación Mom 003 del Museo Arqueológico de la Casa del Marqués de San Jorge, fue \\ encontrada en una cueva del departamento de Santander, Colombia, y donada al Fondo de \\ Promoción de la Cultura del Banco Popular hace más de treinta años. A esta momia ya se le \\ había determinado el género por estudio del cromosoma Y por PCR; se sometió a estudios \\ radiológicos por tomografía computarizda y se tomaron muestras de tejido pulmonar, de la \\ columna vertebral y de piel para el estudio de tuberculosis. Los estudios escanográficos \\ mostraron con claridad la presencia de tuberculosis vertebral, responsable de su importante \\ cifosis angular dorsal o mal de Pott. AI ADN obtenido a partir del tejido pulmonar se le hizo \\ ribotipificación con genes de la fracción $16 \mathrm{~S}$ del ribosoma, los cuales fueron positivos. Esto \\ demuestra la existencia de la tuberculosis en la Colombia prehispánica.
}

Palabras clave: momia, tuberculosis, ribotipificación, mal de Pott.

Demonstration of tuberculosis by DNA ribotyping of Mycobacterium tuberculosis in a Colombian prehispanic mummy

The mummy studied belonged to the prehispanic Guane society. According to the Mom 003 record of the Archaeological Museum of the House of the Marqués de San Jorge, it was found in a cave in the department of Santander, Colombia, and was donated to he Culture Promotion Fund of the Banco Popular more than 30 years ago. The gender of the mummy had been previously determined by PCR study of the Y chromosome; computerized tomography studies (CT) were carried out and samples of lung tissue, vertebral spine and skin were taken for studying tuberculosis. The CT scans clearly show the presence of spinal tuberculosis, accounting for its important angular cifosis or Pott's disease. DNA obtained from lung tissue was submitted to ribotyping with genes of the $16 \mathrm{~S}$ ribosomal subunit, giving positive results. This finding demonstrates the presence of tuberculosis in prehispanic Colombia.

Key words: mummy, tuberculosis, ribotyping, Pott's disease.

Hace más de veinticinco años que los investigadores colombianos mencionan la existencia de la tuberculosis entre las sociedades prehispánicas que habitaron el territorio

\section{Correspondencia: \\ Hugo Sotomayor \\ hsotomayort@umng.edu.co}

Recibido: 27/01/04; aceptado:12/02/04 colombiano; la presencia de esta enfermedad se ha demostrado en otras partes de América por estudios microbiológicos en un caso y por estudio del ADN en tres casos en poblaciones prehispánicas diferentes a las colombianas. En este informe se documenta la confirmación por medio del análisis del ADN específico para Mycobacterium tuberculosis que esta enfermedad existió en la Colombia prehispánica. 
El investigador peruano J. E. García fue el primero en documentar la presencia de tuberculosis en restos humanos prehispánicos americanos por medio del examen de patología macroscópica (1). En 1973, Allison, Mendoza y Pessia reportaron un caso de tuberculosis en una momia precolombina peruana al demostrar un organismo ácido alcohol resistente (2); en 1991 se demostró M. tuberculosis en una momia peruana con la técnica de ADN y, posteriormente, se han publicado reportes de confirmación de $M$. tuberculosis en momias de diferentes partes del mundo por medio de la técnica del análisis del ADN (3), incluso en Chile y Perú $(4,5)$.

En Colombia, J. V. Rodríguez, A. M. Boada y C. Arregocés hicieron descripciones morfológicas y radiológicas de casos de tuberculosis en restos óseos de columna vertebral recogidos en lo que fue el territorio muisca (6-9). W. Romero estudió radiológicamente en 1995 la momia motivo de esta presentación (10). En 1992, Correal y Flórez estudiaron por imaginología, dos casos de momias guane con lesiones compatibles con tuberculosis pulmonar (11). Esta enfermedad también ha sido planteada por Sotomayor como diagnóstico diferencial en el estudio de la representación que de las enfermedades hicieron las culturas prehispánicas en Colombia (12-14).

El poblamiento de la cordillera oriental de los Andes colombianos, en particular en el sitio de El Abra, Cundinamarca, en el altiplano cundiboyacense, tiene fechas tan remotas como el 12.400 antes del presente $(15,16)$. Los pueblos conocidos de la familia lingüística chibcha asentados en la cordillera oriental fueron los muiscas, los laches, los guanes y los chitareros (17); también pertenecen a esta familia los pueblos contemporáneos arhuacos (kogui, ika y wina) de la Sierra Nevada de Santa Marta, los tunebos o u'wa del piedemonte de Arauca y Casanare, y los cunas del Darién; son microfilos chibcha los bari de la Serranía de Perijá y los chimila de las Ilanuras centrales del departamento del Magdalena y de partes del departamento del Cesar $(18,19)$.

Los guane ocuparon la región de los cañones de los ríos Chicamocha, Suárez y Fonce y las mesetas de Barichara, Los Santos y Bucaramanga, al norte del territorio muisca. La ocupación guane tuvo dos fases: una temprana que se inició alrededor del siglo VIII o IX d.C. y duró hasta el siglo XIII, que se ubicó principalmente hacia las regiones del norte y oriente del departamento de Santander, en la Mesa de Bucaramanga y de Los Santos, sobre el sector inferior del cañón del río Chicamocha y en la zona aledaña a los páramos del suroriente del departamento de Santander y una tardía que arrancó a partir de ese momento y duró hasta la época de la conquista española, ubicada básicamente al sur y al occidente de Santander, incluso el valle del Suárez, la meseta de Barichara, al alto Chicamocha, las regiones de Socorro y Oiba y la Serranía de los Cobardes $(20,21)$.

La momificación cultural o artificial practicada en lo que hoy es Colombia, en lugares tan diferentes como el Darién, la serranía de Perijá, el departamento de Santander y el altiplano cundiboyacense casi siempre se realizó por la técnica de desecación por el calor del fuego y sin practicar la evisceración, aunque existen excepciones. En la mayoría de grupos, la complejidad de la momificación y de los ritos funerarios asociados variaron según las diferencias sociales intratribales. Se sabe por estudios de datación con radiocarbono que la momificación tuvo un rango temporal que va desde 200 d.C. hasta 1520 d.C. (22).

La mayoría de las más de 70 momias documentadas en Colombia - concentradas en los Andes Orientales, 54 chibchas, entre muiscas, laches y guanes, y 16 yuko - no tienen un contexto de estudio arqueológico y una datación precisa. Valverde afirma que no se puede establecer una separación clara entre los pueblos de lengua chibcha (muiscas, guanes y laches) sobre la base de los patrones de momificación (23).

\section{Materiales y métodos}

A la momia objeto del estudio (figura 1) se le practicó un estudio de tomografía computarizada (TC) en la Sección de Imágenes Diagnósticas del Hospital Militar Central, Bogotá. El estudio por TC se inició con un registro lateral en la posición 'fetal' actual de la momia, para estudiar la cifosis torácica baja; luego, se obtuvieron imágenes axiales cada $8 \mathrm{~mm}$ desde T8/9 hasta L3 para estudiar los 
segmentos torácico y lumbar de interés y hacer reconstrucciones parasagitales. Un segundo barrido helicoidal, usado para las reconstrucciones tridimensionales (figura 2), cubrió la totalidad de la momia, con cortes de arriba abajo de $5 \mathrm{~mm}$.

Las muestras para la investigación del ADN de $M$. tuberculosis con la técnica de reacción en cadena de la polimerasa (PCR) se obtuvieron con un broncoscopio pediátrico. El broncoscopio se introdujo por la parte anterior ausente del hemitórax derecho, a través de la cual se visualizó con facilidad la región de la giba de la columna vertebral y, por la parte superior, ausente la cabeza, por donde se visualizó la tráquea. Se obtuvieron sendas muestras muy pequeñas de tejido óseo de la columna vertebral, del tejido broncopulmonar y del tejido expuesto al exterior de la parte torácica izquierda. Posteriormente, se obtuvo una pequeña muestra de piel del pie izquierdo que se entregó al mismo laboratorio especializado en estudios de ADN. Además, por solicitud de este laboratorio, se entregó una pequeña muestra ósea de un cadáver humano que reposaba en el anfiteatro de la Facultad de Medicina de la Universidad Militar Nueva Granada, con el objeto de estandarizar la técnica de extracción del ADN óseo.

Las muestras se sometieron a los procedimientos habituales de investigación del ADN con la técnica de PCR. Con esta técnica se busca identificar IS6110, un segmento de ADN único de $M$. tuberculosis, es decir, la secuencia de inserción repetitiva semejante al elemento de 1.361 bp que se correlaciona altamente con el diagnóstico clínico. Esta técnica excluye otras especies de Mycobacterium que se pueden encontrar en el suelo y contaminar los restos enterrados (24).

El procedimiento para el aislamiento y el estudio del ADN de la momia fue muy cuidadoso para evitar la contaminación con ADN contemporáneo y siguió las normas establecidas para el manejo de muestras ancestrales (25-27).

\section{Resultados}

La momia pertenece a la sociedad guane. Según consta en la ficha de clasificación Mom 003 del Museo Arqueológico de la Casa del Marqués de San Jorge, fue encontrada en una cueva del

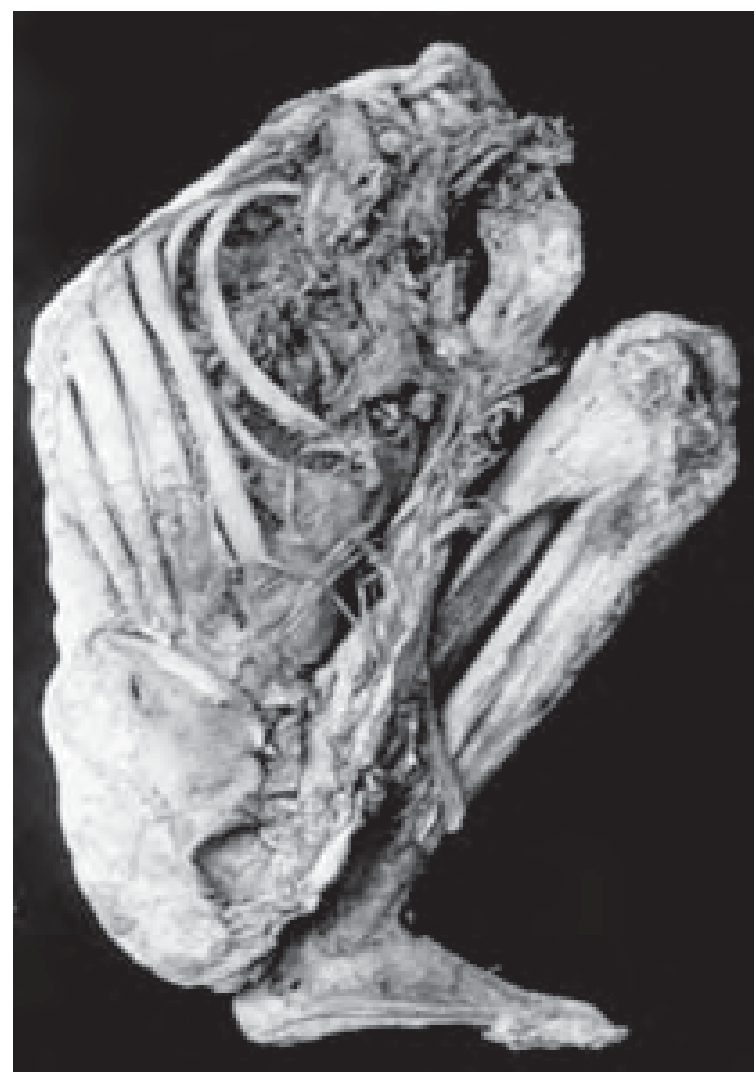

Figura 1. Fotografía de la momia guane (Mom 003, Museo Arqueológico de la Casa del Marqués de San Jorge).

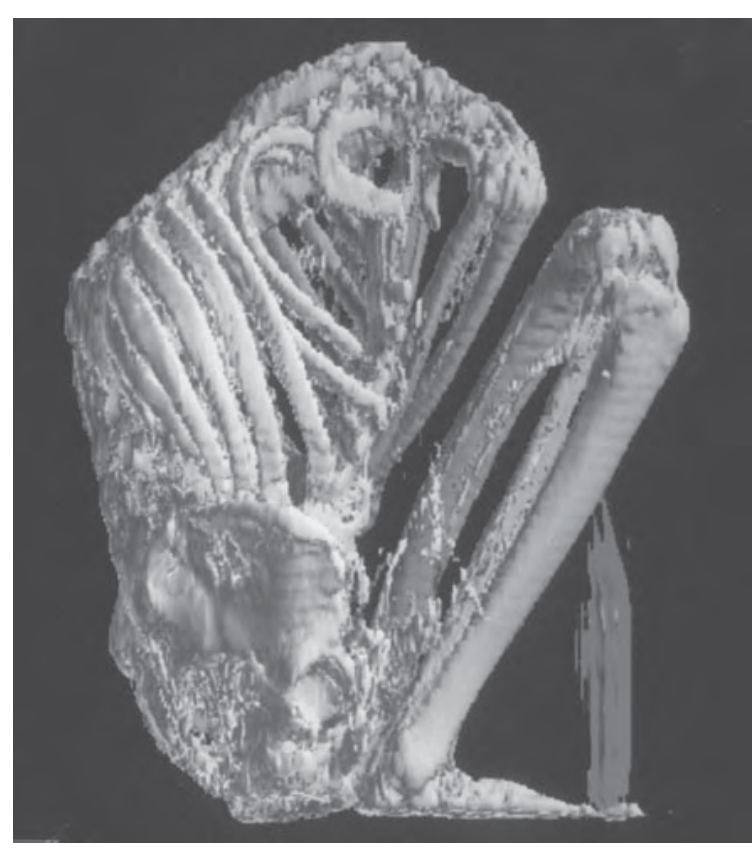

Figura 2. Reconstrucción tridimensional de la momia guane. 
departamento de Santander, Colombia, y fue donada al Fondo de Promoción de la Cultura del Banco Popular hace ya más de treinta años. Aunque no tiene una fecha claramente establecida, con toda probabilidad es prehispánica por lo antes anotado.

Esta momia ya se había sometido a estudios radiológicos y se le determinó el género con la técnica de PCR para el antígeno Y $(11,28,29)$; este hallazgo confirmó su apariencia física de sexo masculino.

Según el estudio previo de esta momia (30), la edad estimada en el momento de la muerte del sujeto masculino oscilaba entre los 30 y los 42 años; su estatura, según la longitud de la tibia, comparada con el patrón mongoloide, era de 1,63 $\mathrm{m} \pm 0,03 \mathrm{~m}$. En este estudio radiológico simple se identificó una osteólisis selectiva a la altura de las vértebras T11 y T12 que provocó una destrucción ósea y el consecuente colapso de las vértebras con la angulación raquídea característica y engrosamiento de la cortical en la proximidad del trocánter menor del fémur izquierdo, posiblemente por una periostitis con drenaje espontáneo del proceso infeccioso a través del músculo psoas (30).

\section{Estudio tomográfico}

El nuevo estudio imagenológico demostró lo siguiente: presencia de una giba cifótica con epicentro en T11 (figura 3, 4 y 5); ausencia de la cabeza, las vértebras cervicales desde C5, el miembro superior y el inferior derechos, cintura escapular y clavícula; se advierte, también, el desplazamiento de algunas costillas superiores en sentido inferior y, quizá, la desarticulación de las primeras.

Los hallazgos tomográficos se reportaron así:

1) Momia no eviscerada con defectos en la parrilla costal superior derecha, decapitación entre C4/ 5 , desmembración con escápula del miembro superior derecho y del miembro inferior derecho por desarticulación coxofemoral. Se aprecia una giba cifótica en T11/12 por colapso parcial del cuerpo de T11 del cual se encuentra conservado el arco posterior.

2) Existen nódulos de Schmörl en T10/11 y T11/
12, que deben distinguirse de las lesiones erosivas. Los primeros tienen suelo esclerótico grueso y son centrales con relación a la porción nuclear del disco correspondiente, mientras que las lesiones erosivas son de menor diámetro, sin contorno escleroso, más periféricas y algunas rompen la corteza del cuerpo, por ejemplo, a nivel de T12, L1 y L2.

3) Se encuentra una serie de lesiones en los cuerpos de T10, T11 y T12 con pérdida de su aspecto normal; hay lesiones erosivas líticas que siguen la orientación de las estructuras vasculares venosas. Las venas basivertebrales son particularmente numerosas en el tercio inferior de T10. El cuerpo de T11 se acuñó y se colapsó en cuña reduciéndose de tamaño también en sentido transverso y muestra una cavidad antero-lateral izquierda al cuerpo T12. Hay también erosiones posteriores al cuerpo $L 1$ en el tercio superior; aquí hay cierta esclerosis que rodea medialmente las del lado derecho.

4) Se ve una calcificación dentro del canal raquídeo que predomina en la mitad anterior derecha que se extiende desde T11/12 hasta L3.

5) Desde el punto de vista óseo, no hay otras alteraciones vertebrales, costales, ilíacas con la excepción de la vértebra L5 transicional fija a la derecha.

6) Desde el punto de vista visceral, hay deterioro por la intromisión al hemitórax derecho en el pulmón correspondiente, con colapso en las tomas basales. El izquierdo está mejor expandido. Las vísceras abdominales no son fáciles de diferenciar y parecen recogidas. Hay contenido calcificado en el colon ascendente (figura 6).

7) Por la imagen lateral panorámica, se encuentran vértebras sanas en los segmentos que no están comprometidos y la densidad sugiere una edad cronológica de una persona joven.

\section{Estudio del ADN de Mycobacterium tuberculosis}

La tipificación molecular del ADN ancestral generó la amplificación de un fragmento de 1.100 pb, 


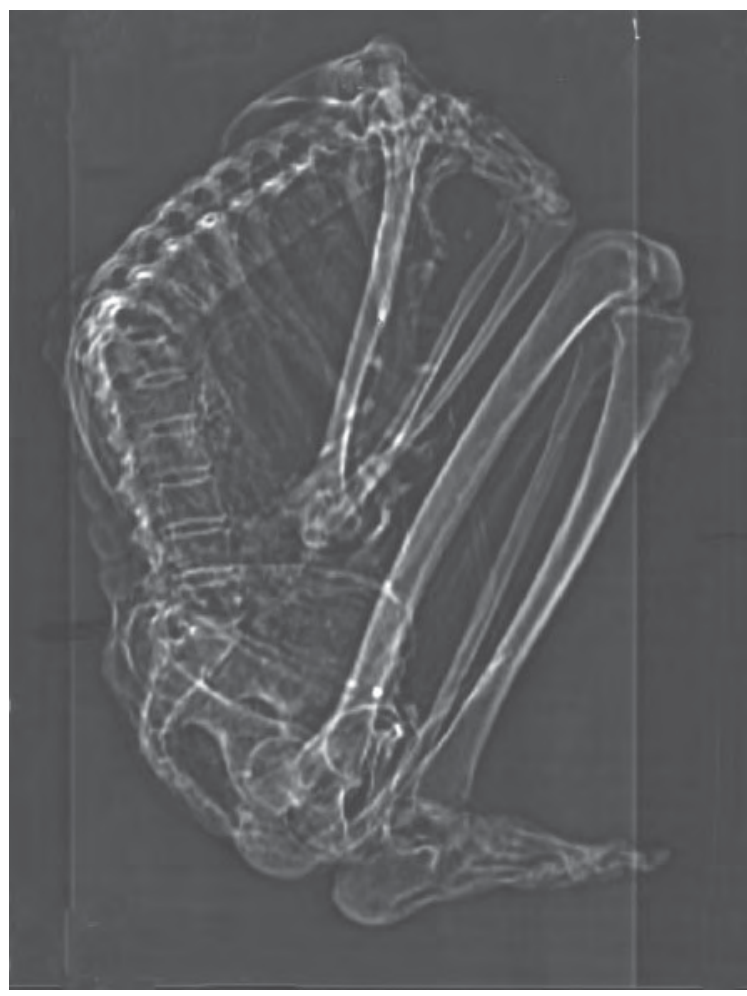

Figura 3. Radiografía digital localizadora; lesión en cuerpos vertebrales $\mathrm{T} 10 / \mathrm{T} 11$.

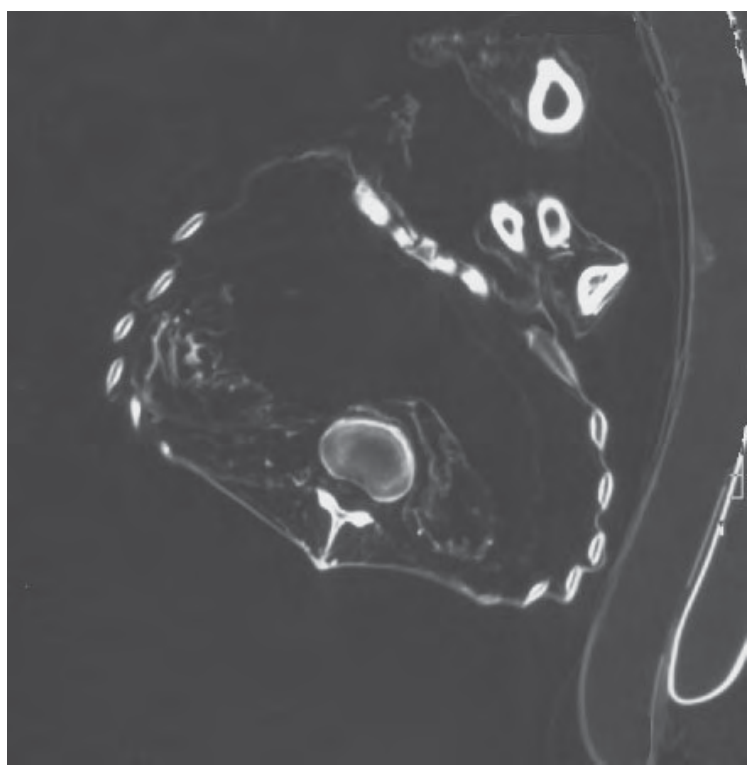

Figura 5. Visión escanográfica transversal: engrosamiento pleural con calcificación en el lado izquierdo.

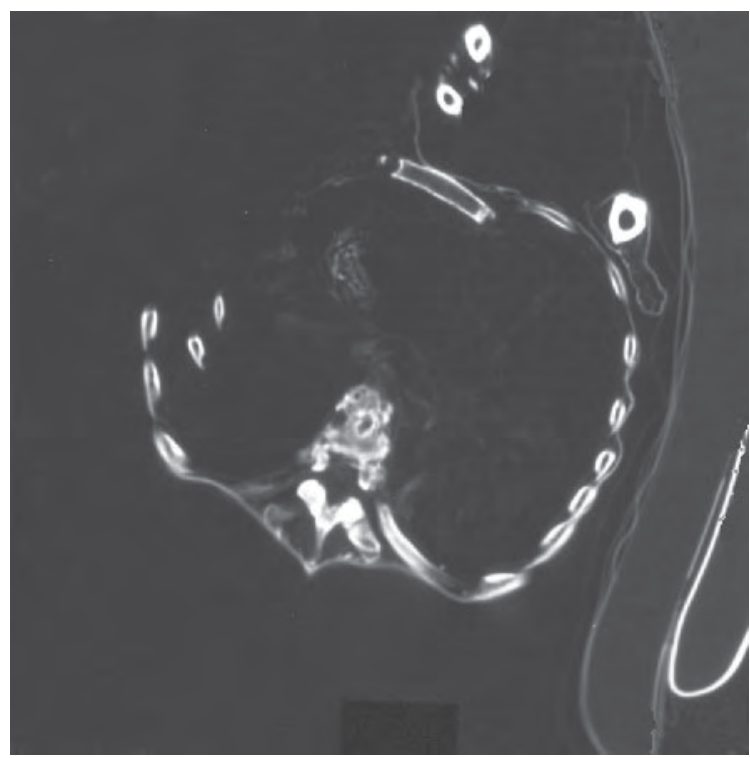

Figura 4. Visión escanográfica transversal: acuñamiento de los cuerpos vertebrales T10/T11.

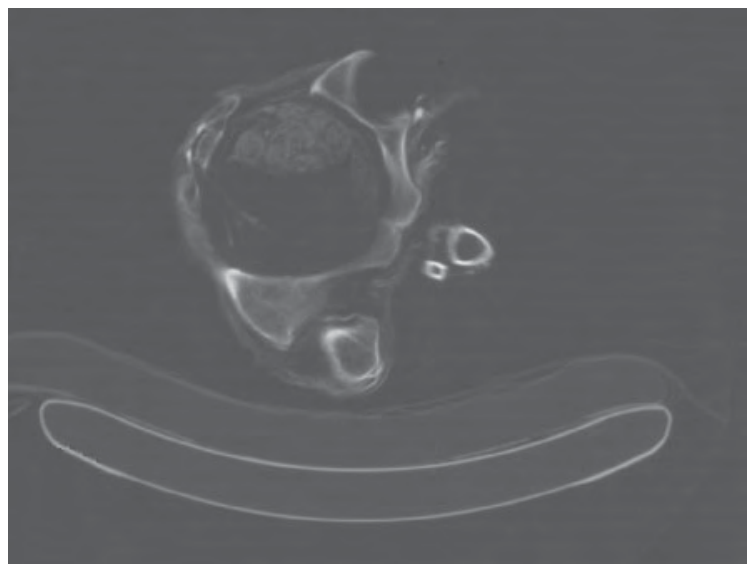

Figura 6. Visión escanográfica transversal: material denso en colon ascendente. 


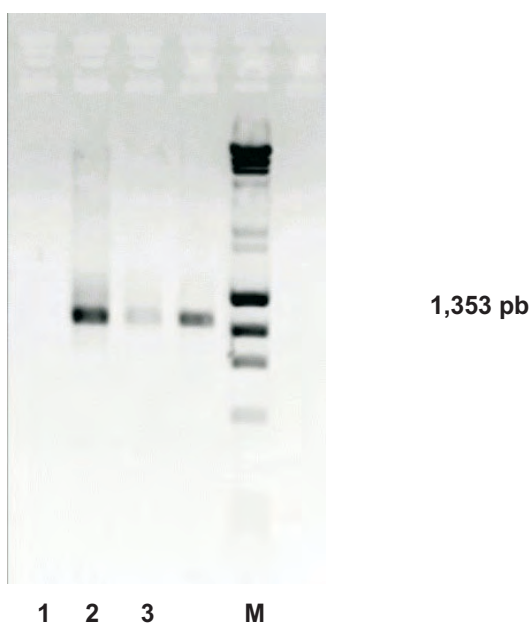

1 ADN piel $1 / 10$

2 ADN pulmón $1 / 10$

3 ADN pulmón $1 / 10$

$4 \mathrm{C}+$ E. coli

M lambda HindIIL+Phi Haelll

Amplificación con los

oligonucleótidos $16 \mathrm{~S} 1 / 16 \mathrm{~S} 2$

(subunidad ribosómica 16S)

Figura 7. Amplificación con los oligonucleótidos 16S1/16S2 (subunidad ribosómica 16S) positiva para Mycobacterium tuberculosis en el tejido pulmonar.

correspondiente a un segmento del gen del ADN ribosómico $16 \mathrm{~S}$ específico de $M$. tuberculosis (figura 7).

\section{Discusión}

La tuberculosis humana es una infección aguda o crónica de los tejidos blandos o del esqueleto producida por $M$. tuberculosis o M. bovis. Las infecciones humanas producidas por otras especies de Mycobacterium son las llamadas micobacteriosis atípicas. La infección humana producida por $M$. tuberculosis usualmente se adquiere por la vía aérea o respiratoria y la enfermedad comienza como una infección broncopulmonar. El reservorio de $M$. tuberculosis es primordialmente el humano infectado. Los reservorios de $M$. bovis son los animales, en especial, el ganado vacuno, aunque el tipo de animal específico varía geográficamente y con las prácticas culturales. El consumo de alimentos de los animales infectados, especialmente la leche, hace que la bacteria penetre en la región orofaríngea y los ganglios cervicales y, menos frecuentemente, al tracto gastrointestinal. Sin embargo, las diferencias en el patrón de compromiso de los órganos y tejidos son primariamente un producto de la ruta de la infección. Si M. bovis penetra por la vía respiratoria es capaz de reproducir las lesiones que produce M. tuberculosis.

La tuberculosis es una enfermedad bifásica: una fase de una infección primaria y una fase de reinfección o reactivación. La infección humana por M. tuberculosis usualmente se inicia como una infección pulmonar y se puede diseminar a otros aparatos y sistemas por el mecanismo de la deglución de las secreciones infectadas o por vía hemática.

En los estudios paleopatológicos cuando se conserva el pulmón, el hallazgo del complejo de Ghon es generalmente un distintivo suficiente para hacer el diagnóstico. Cuando únicamente se encuentra tejido esquelético diferente de la columna vertebral, a menudo el diagnóstico no tiene el valor de precisión que se tiene cuando se dispone de restos de la columna y, en especial, cuando se encuentran las vértebras con las características del mal de Pott (31).

El microorganismo llega a la columna a través de un foco en el pulmón, el aparato urinario u otros sitios, generalmente por la vía hematógena o por contacto estrecho con una víscera lesionada.

Se sabe que la mitad de los casos de compromiso de la columna ocurren antes de la edad de los 10 años y que el pico de presentación de la cifosis angular o mal de Pott aparece entre los 20 y los 30 años. El $50 \%$ de las personas con infección tuberculosa de la columna presenta mal de Pott, que afecta especialmente la región comprendida entre T8 y L4.

Las características más importantes de las lesiones de la columna vertebral en el contexto paleopatológico son: el compromiso frecuentemente de una a cuatro vértebras; la destrucción ósea es prominente, mientras que la regeneración ósea es rara; el compromiso de la parte anterior del cuerpo vertebral es frecuente; la cifosis es más frecuente en la columna torácica; el compromiso vertebral óseo, aunque se puede presentar, no es frecuente, con la excepción de los que se presentan en el atlas y el axis; los abscesos 
extravertebrales son frecuentes, se presentan entre el $50 \%$ y el $90 \%$ de los casos; aunque la fusión espontánea ocurre, como expresión de la regeneración ósea masiva, es muy rara (32).

Las alteraciones de la columna vertebral se clasifican en cinco grandes grupos: malformaciones congénitas, procesos degenerativos, enfermedades infecciosas, neoplasias y lesiones traumáticas. Recientemente, P. Gerszten, E. Gerszten y M.J. Allison publicaron un excelente trabajo sobre las enfermedades de la columna de 703 momias, 415 chilenas y 288 peruanas; encontraron varios casos de espina bífida, un caso de escoliosis congénita, varios casos de osteoartritis degenerativa, un caso de tuberculosis, un caso de metástasis y documentaron un caso de lesión de columna por una flecha, otro caso de fractura de T12 por compresión y otro que generó una fusión traumática de L3 a S1 (32). En esta investigación, aunque los investigadores encontraron tuberculosis, no mencionan nódulos de Schmörl dentro del grupo de enfermedades degenerativas y traumáticas.

Los nódulos de Schmörl hallados en la momia guane se pueden clasificar, a pesar del debate sobre su origen, en la categoría de procesos degenerativos o traumáticos de los discos intervertebrales. Estos nódulos, que no son más que la protrusión del núcleo pulposo de un disco intervertebral dentro de la vértebra después de haber comenzado como un defecto de la corteza o de la placa final del cuerpo vertebral, se ven en los estudios habituales de TC como una región hipodensa con bordes esclerosos dentro del cuerpo vertebral. Varios estudios han señalado su relación con la bipedestación humana, su mayor frecuencia en mujeres que en hombres a partir de la adolescencia y que afectan principalmente las vértebras de T8 a L2.

La tuberculosis, aunque afecta varios huesos y articulaciones del cuerpo, tiene predilección por la columna vertebral hasta en el $50 \%$, especialmente por la región de $T 8$ a $L 4$, y da origen el característico mal de Pott. Algunos autores piensan que las lesiones espinales son más frecuentes que la suma de todos los otros sitios de tuberculosis esquelética. Se ha afirmado clásicamente que el compromiso de más de 4 vértebras es raro, que la destrucción del tejido esquelético es la característica más prominente y que la regeneración ósea es rara.

Los abscesos extravertebrales tuberculosos son frecuentes hasta en $50 \%$ a $90 \%$ de los casos. Los más frecuentes son los localizados anteriormente a la columna torácica baja y lumbar.

Si bien en el mal de Pott la tuberculosis es la más probable de las causas, a juzgar por la casuística clínica moderna y los registros de restos humanos antiguos $(33,34)$ hoy esa alta probabilidad alta se puede convertir en certidumbre con los estudios del ADN.

Desde el punto de vista escanográfico, se trata de una momia incompleta con enfermedad infecciosa en T11/12 con absceso ahusado paravertebral y, quizá, epidural compatible con etiología tuberculosa en una persona joven con preexistencia de nódulos de Schmörl. Se trata de una momia que tiene una patología degenerativa y una infecciosa, muy probablemente tuberculosa, en columna vertebral.

La ribotipificación del ADN ancestral de la momia permitió concluir, sin lugar a dudas, que este individuo sufrió de tuberculosis por $M$. tuberculosis, lo cual indica la presencia de la enfermedad en la Colombia prehispánica. Este hallazgo concuerda con los ya encontrados en Chile y Perú (1-5).

\section{Agradecimientos}

Los autores agradecen a Álvaro Tafur y Fernando Medina del Servicio de Imágenes Diagnósticas del Hospital Militar Central y a Ana María Quintero de la Unidad del Servicio de Resonancia Magnética de la Clínica del Country por su interés y gran colaboración en el estudio imagenológico de la momia.

\section{Referencias}

1. García JE. La tuberculosis en los antiguos peruanos. Actualidad Médica Peruana 1940;5:274-91.

2. Allison MJ, Mendoza D, Pezzia A. Documentation of a case of tuberculosis in precolumbian America. Am Rev Respir Dis 1973;107:985-91. 
3. Christensenn D. Pre-Columbian mummy lays TB debate to rest. Science News 1994;145:181.

4. Arriaza BT, Salo W, Aufderheide AC. Pre-Columbian tuberculosis in Northern Chile: molecular and skeletal evidence. Am J Phys Anthropol 1995;98:37-45.

5. Lombardi GP. Detección de Mycobacterium tuberculosis en una momia de la cultura Nazca con mal de Pott. Resúmenes, III Congreso Internacional de Estudios sobre Momias, Cartagena de Indias, 1995.

6. Rodríguez JV. Análisis osteométrico, osteoscópico, patológico y dental de los restos óseos de Soacha. Informe preliminar. Bogotá: Instituto Colombiano de Antropología; 1987.

7. Rodríguez JV. La tuberculosis en Colombia prehispánica. Innovación y Ciencia 1998;7:58-64.

8. Boada AM. Las patologías óseas en la población de Marín. Boletín de Arqueología1988; 3:1-23.

9. Arregocés C. Paleopatología de algunos restos de una muestra esqueletal de Soacha, Cundinamarca, con especial referencia a la tuberculosis (tesis). Bogotá: Universidad Nacional de Colombia; 1989.

10. Romero WM. Mal de Pott en momia de la colección del museo arqueológico Marqués de San Jorge. Maguaré 1998;13:99-115.

11. Correal G, Flórez I. Estudio de las momias guanes de la Mesa de los Santos, Santander, Colombia. Rev Acad Col Cienc Exac Fis y Nat 1992;18:283-90.

12. Sotomayor H. Enfermedades en el arte prehispánico colombiano. Boletín Museo del Oro del Banco de la República 1990; 29:124-6.

13. Sotomayor $\mathbf{H}$. Enfermedades y símbolos de poder y trascendencia en cerámicas prehispánicas colombianas. Pediatría 1993;28:63-73.

14. Sotomayor H, Correal G. Iconografía de patologías en la colección de orfebrería del Museo del Oro del Banco de la República. Boletín Museo del Oro del Banco de la República 1995;38-39:172-5.

15. Correal G, van der Hammen T. Artefactos líticos en abrigos rocosos de El Abra, Colombia. Revista Colombiana de Antropología 1969;14:9-51.

16. Rodríguez JV. Los chibchas: pobladores antiguos de los Andes orientales. Adaptaciones bioculturales. Bogotá: Fundación de Investigaciones Arqueológicas Nacionales, Banco de la República; 1999. p.17-47.

17. Rodríguez JV. Los chibchas. Adaptación y diversidad en los Andes orientales de Colombia. Bogotá: Departamento de Antropología, Facultad de Ciencias Humanas, Universidad Nacional de Colombia; 2001. p.9-16.

18. Instituto Caro y Cuervo. Lenguas indígenas de Colombia: una visión descriptiva. Bogotá: Instituto Caro y Cuervo; 2000.
19. Instituto Colombiano de Antropología. Introducción a la Colombia amerindia. Bogotá: Instituto Colombiano de Antropología; 1987.

20. Lleras R, Vargas A. Palogordo: la prehistoria de Santander en los Andes orientales. Boletín del Museo del Oro, Banco de la República 1990;26:65-129.

21. Lleras R. La arqueología de Santander: Los guanes. En: Fondo de Promoción de la Cultura, Arte de la tierra. Muiscas y guanes. Colección Tesoros Precolombinos. Fondo de Promoción de la Cultura. Bogotá: Banco Popular; 1989. p.17-24.

22. Aufderheide AC. Mummies from Colombia. En: Cambridge University Press. The scientific study of mummies. Cambridge, United Kingdom: University Press; 2003. p.96-102.

23. Valverde AM. Análisis funcional de la momificación prehispánica, el caso del altiplano cundiboyacense (tesis). Bogotá: Universidad de los Andes; 2002.

24. Salo W, Aufderheide A, Buikstra J, Holcomb TA. Identification of Mycobacterium tuberculosis DNA in a pre-Columbian mummy. Proc Natl Acad Sci USA 1994; 91:2091-4.

25. Hermann JL, Hummel P. Ancient DNA. Berlin: SpringerVerlag; 1999.

26. Forbes BA, Hicks KE. Direct detection of Mycobacterium tuberculosis in respiratory specimens in a clinical laboratory by PCR. J Clin Microbiol 1993;31:1688-94.

27. Honorè-Bouakline S, Vincensini JP, Giacusso V, Lagrange PH, Hermann JL. Rapid diagnosis of extrapulmonary tuberculosis by PCR: impact of sample preparation and DNA extraction. J Clin Microbiol 2003; 41:2323-9.

28. Romero WM, Herrasti L. Cifosis angular de la columna vertebral: identificación del mal de Pott en una momia guane de Colombia. III Congreso Internacional de Estudios sobre Momias. Arica, Chile, 1998.

29. Burgos J, Clavijo O, Fernández C. Determinación del sexo en momias empleando PCR. II Encuentro de Medicina y Arqueología en Colombia, Santafé de Bogotá, Colombia, 1996.

30. Etxeberría F, Romero WM, Lerrasti L. Cifosis angular de la columna vertebral: identificación del mal de Pott en una momia guane prehispánica de Colombia. Chungara 2000;32:41-8.

31. Aufderheide AC, Rodríguez-Martín C. Tuberculosis. En: Cambridge University Press. The Cambridge encyclopedia of human paleopathology. Cambridge: Cambridge University Press; 1998. p.118-41.

32. Gerszten P, Gerszten E, Allison MJ. Diseases of the spine in South American mummies. Neurosurgery 2001; 48:208-13 
33. Ortner DJ, Putschar W. Identification of pathological conditions in humans skeletal remains. Washington, D.C.: Smithsonian Institution Press; 1985. p.141-76.
34. Aufderheide AC, Rodríguez-Martín C. Tuberculosis. En: Cambridge University Press. The Cambridge encyclopedia of human paleopathology. Cambridge: Cambridge University Press; 1998. p.118-41.

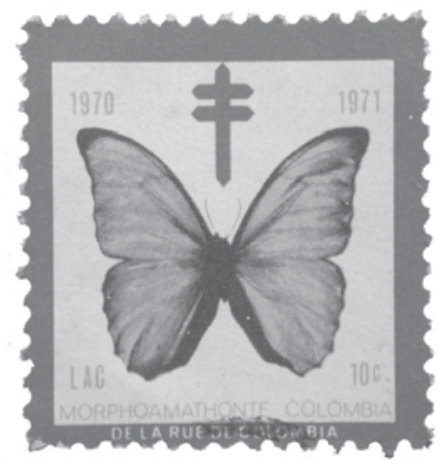

